than $£ 100$ million extra to compensate universities for the reduction of fees for home students.

For many British universities and academics, last week's announcement will seem to bear directly on the pay negotiations now under way between the universities and university teachers, represented by the Association of University Teachers. For the grants committee's letter does formally confirm the UK government's intention that the university grant for the coming year should include only 3 per cent for salary increases. While there have been some suggestions, at the University of Aberdeen for example, that academics might forgo pay increases in the present round of pay negotiations, the union nationally is asking for 14 per cent, 12 per cent to compensate for price inflation in the past year and 2 per cent to make good the erosion of academic pay.

The allocation of funds for the coming academic year has apparently been made in the light of universities' accounts of how they plan to adjust to falling budgets. The grants committee is apparently planning to keep back some $120-30$ million of the total government grant to finance the more interesting of universities' intended innovations. The new letter to universities pleads, however, that universities having to reduce costs should not take the knife to easily eliminated but academically important minority departments.

The committee has also shared out among its dependent universities the annual government grant for equipment and furniture, fixed last month at $£ 83.6$ million. While the Department of Education and Science said last week that the grant is "consistent with the aim of maintaining standards ...", the grants committee seems strongly to hold that the grant is at least one third too small.

For the more distant future, the grants committee seems to expect that there will be a return to "level funding" after the present contraction is over in 1983-84, but does not know whether the provisional budget for 1984-85 published in the government's expenditure white paper in March will be adjusted upwards if inflation exceeds the supposed 5 per cent a year.

The grants committee itself plans to spend much of the coming year studying possible changes in the social function of universities, especially in continuing education. It remains unclear what will befall those universities which fail to meet the grants committee's targets for reduced student numbers by the end of 1983-84. The sentence in last year's letter suggesting that universities failing to meet their targets would be penalized is not echoed in those sent out last week, but the committee is apparently guessing that if the government should be disappointed with the universities' performance, and should cut the total budget by the extra cost of student maintenance, the budgets of the universities responsible will also be cut.
London medical teaching

\section{Merger fever}

While the rest of the University of London continues to agonize about its future, the undergraduate medical schools are at last beginning to implement a plan designed to save 10 per cent of the university's medical education bill by 1983-84 The outlook for dental education also looks brighter since the five dental deans recently agreed to move the school at the Royal Dental Hospital from its premises in Leicester Square to one of the university's four other dental schools. But the future of the postgraduate medical institutes, whose finances have been particularly badly hit by the shortfall in the number of overseas students, will not be tackled until July.

After almost two years of often bitter wrangling, the undergraduate medical schools, collectively the largest source of trained physicians in the United Kingdom, finally agreed on a plan at the end of last year. The dispute began after a committee chaired by Lord Flowers, rector of Imperial College, recommended at the beginning of 1980 that the university's 34 medical and dental institutions should amalgamate into six large conglomerates.

That debate was overtaken by events. The government's announcement at the end of 1980 of large cuts in university education concentrated minds. The plan adopted was designed to increase opportunities for pre-clinical students to choose between medical and multi-faculty schools, and provide access to certain major disciplines, clinical pharmacology, therapeutics and community medicine.

Three of the medical schools, those at the Royal Free, St George's and St Mary's hospitals, are to remain much as they are. The others are to form some type of association either with another medical school or with a multi-faculty college. Thus the medical schools of Charing Cross and Westminster hospitals are to merge. So too are those at the Middlesex Hospital and University College. The schools at St Thomas's and Guy's hospitals are to form a united medical school next autumn and those at St Bartholomew's and the London hospitals are to work towards formation of a joint school. The school at King's College Hospital is to be administered from King's College in the Strand.

The outstanding problem is whether the plan can be implemented in time to make the necessary savings. Schools that must merge will be combining courses, departments and administrations and reorganizing accommodation. St Thomas's and Guy's hospitals, however, will retain their separate schools but merge administration.

The merger of the London and St Bartholomew's schools will take longer. The promise by the University Grants Committee to finance new accommodation for the joint school at Queen Mary College, a multi-faculty institution, still stands. But the grants committee is now looking for existing buildings which may become available when Queen Mary College has itself trimmed its operations to match its reduced grant.

The reorganized medical schools will be expected to maintain their aggregate student population. But the reorganization alone will not by itself yield the necessary savings. So student:staff ratios are to decline from the present 1:7.4 in preclinical studies to $1: 10$ by $1983-84$ and from 1:6 in clinical studies to $1: 7$.

Judy Redfearn

\section{Polish sciences}

\section{Nothing to read \\ Poland's endemic hard-currency} problems are posing a major threat to Polish science. The purchase of Western scientific journals is virtually impossible, and according to the Warsaw daily Zycie Warszawy, last year no subscriptions were paid to foreign suppliers at all, so that by October the country had run up a debt of about US\$8 million for journals supplied against invoices.

This year, some $\$ 5$ million have been allotted for the purchase of journals, but this is only half the quota for 1980 and less than 20 per cent of the 1978 level. Polish scientists have had to resort to various stratagems to keep up with their reading. Photocopies of Current Contents were displayed on the noticeboards of institutes and universities and scientists requested a photocopy of articles they required from the Academy of Science or else through interlibrary loan. Martial law, however, meant that very tight security controls were imposed on photocopiers, lest they be used for the production of protest leaflets.

At the same time, their other main source of new publications - offprints and duplicate copies of journals requested from foreign colleagues - has been considerably reduced. Under martial law, the mails are considerably delayed by the censorship, scientific visits to and from Poland have been significantly curtailed, and many Westerners are apparently disinclined to send material to their Polish colleagues for fear that journals arriving from abroad might attract the attention of the security authorities.

So far, little has been done abroad to relieve the situation. The British Council has allotted $£ 25,000$ for the purchase of journals for Polish academic institutions; in the United States, however, the view is by no means unanimous that aid would be proper until martial law comes to an end.

But to Polish scientists the situation is a matter of intellectual survival. Letters to Western colleagues emphasize that without an emergency supply of journals to tide them over the current crisis, Polish scientists will rapidly fall behind the world scientific community, and catching up, when dollars become available again, will be virtually impossible.
Vera Rich 